\title{
Novel diagnosis and therapy for hepatoma targeting HBV-related carcinogenesis through alternative splicing of FIR (PUF60)/FIR $\Delta$ exon2
}

\author{
Kazuyuki Matsushita', Tyuji Hoshino ${ }^{2}$ \\ 'Department of Laboratory Medicine \& Division of Clinical Genetics and Proteomics, Chiba University Hospital, Chiba, 260-8677, Japan. \\ ${ }^{2}$ Department of Physical Chemistry, Chiba University, Chiba 260-8670, Japan. \\ Correspondence to: Dr. Kazuyuki Matsushita, Department of Laboratory Medicine \& Division of Clinical Genetics and Proteomics, Chiba \\ University Hospital, Chiba, 260-8677, Japan. E-mail: kmatsu@faculty.chiba-u.jp
}

How to cite this article: Matsushita K, Hoshino T. Novel diagnosis and therapy for hepatoma targeting HBV-related carcinogenesis through alternative splicing of FIR (PUF60)/FIRAexon2. Hepatoma Res 2018;4:61. http://dx.doi.org/10.20517/2394-5079.2018.81

Received: 18 Jun 2018 First Decision: 24 Jul 2018 Revised: 29 Jul 2018 Accepted: 1 Aug 2018 Published: 29 Sep 2018

Science Editor: Guang-Wen Cao Copy Editor: Cui Yu Production Editor: Zhong-Yu Guo

\begin{abstract}
Aim: Disturbed alternative splicing of far upstream element-binding protein-interacting repressor (FIR) was found to be unable to repress c-Myc transcription and so it might be important for suppressing tumor development. FIR is a splicing variant of poly (U)-binding-splicing factor (PUF60), and forms complex with other splicing factors. FIR/PUF60 is a splicing factor of U2 small nuclear ribonucleoprotein auxiliary factor family, Thus FIR/PUF60 is a multifunctional protein. The expression of exon2-lacking splicing variant of FIR, FIR $\Delta$ exon2, is elevated in many cancer tissues and promotes tumor development by disabling FIR-repression to sustain c-Myc activation. FIR $\Delta$ exon2, as a dominant negative of FIR, opposed apoptosis in cancer cells. FIR/FIR $\Delta$ exon2 interacts with degron pocket of F-box and W (Typ) D (Asp) repeat domain-containing 7 and inhibits proteolysis of substrates proteins. Recently, FIR/PUF60 was identified as a versatile regulator of transcriptional and post-transcriptional steps in expression of hepatitis B virus (HBV) pregenomic RNA (pgRNA) expression.
\end{abstract}

Methods: Small molecular chemical compounds against FIR and FIR $\Delta$ exon2 were screened among 2,3275 chemicals by natural product depository array (RIKEN, Wako, Saitama, Japan).

Results: Nine chemicals against FIR and four chemicals against FIR $\Delta$ exon2 were identified as candidates of interacting chemicals. Interestingly, BK697 contains WD -like structure. Among them, BK697 against FIR $\Delta$ exon2 inhibited hepatoma cell growth.

Conclusion: Therefore, FIR (PUF60)/FIR Dexon2 is multifunctional and applicable for clinical use for HBV suppression and hepatoma treatment. Together, one clue to the development of hepatome diagnosis and therapies directed against FIR/FIR $\Delta$ exon2/PUF60 with small molecular weight chemicals that inhibit HBV cccDNA replication.

\footnotetext{
(@) ( $)$

(C) The Author(s) 2018. Open Access This article is licensed under a Creative Commons Attribution 4.0 International License (https://creativecommons.org/licenses/by/4.0/), which permits unrestricted use, sharing, adaptation, distribution and reproduction in any medium or format, for any purpose, even commercially, as long as you give appropriate credit to the original author(s) and the source, provide a link to the Creative Commons license, and indicate if changes were made.
} 
Keywords: Hepatocellular carcinoma, hepatitis B virus, covalently closed circular DNA, far upstream elementbinding protein-interacting repressor, poly (U)-binding-splicing factor, F-box and W (Typ) D (Asp) repeat domaincontaining 7, natural product depository array, U2AF homology motif, U2AF homology motif ligand motif

\section{INTRODUCTION}

C-Myc is overexpressed in the majority of colorectal cancers and is required for tumor maintenance ${ }^{[1,2]}$. The far upstream element (FUSE) is a sequence required for proper expression of the human $c-M y c$ gene. The FUSE is located $1.5 \mathrm{~kb}$ upstream of $c-M y c$ promoter $\mathrm{P} 1$, and binds the FUSE binding protein 1 (FUBP1), a transcription factor stimulating $c-M y c$ expression in a FUSE dependent manner ${ }^{[3,4]}$. FUBP1 is overexpressed and regulates proliferation and migration of hepatoma cells ${ }^{[5-7]}$. Yeast two-hybrid analysis revealed that FUBP1 binds to a protein that has transcriptional inhibitory activity termed the FUBP1-interacting repressor (FIR), and FIR was found to engage the transcriptional factor IIH [TFIIH/p89/xeroderma pigmentosum type B (XPB)] helicase and repress $c-M y c$ transcription $^{[8]}$. FIR induces apoptosis via c-Myc suppression, and is thus a suitable cancer therapy ${ }^{[9,10]}$. Adenovirus-FIR or Sendai virus-FIR vectors gene therapy for nasopharyngeal cancer were reported ${ }^{[11-14]}$. Up to $60 \%$ of all human genes present at least one alternative splice variant ${ }^{[15]}$. Disturbed alternative splicing (AS) in cancer cells or hepatitis B virus (HBV) virus affect host's immune response ${ }^{[16,17]}$. AS has been documented to play a significant role in human disease and DNA repair in cancers ${ }^{[18-21]}$. A splicing variant of FIR that lacks exon2, FIR $\Delta$ exon2, failed to repress c-Myc and inhibited FIR-induced apoptosis suggesting FIR $\Delta$ exon2 is a dominant negative of FIR in human cancers ${ }^{[2]}$. On the other hand, FIR is a splicing variant form of poly(U)-binding-splicing factor $(\mathrm{PUF} 60)^{[23,24]}$. Anti-PUF60 autoantibodies are reported to be detected in the sera of autoimmune diseases such as dermatomyositis, Sjogren's syndrome or idiopathic inflammatory myopathy ${ }^{[25,26]}$. Further, the combination of anti-FIRs antibodies with other clinically available tumor markers such as anti-p53 antibodies, CEA, and CA19-9 further improved the specificity and accuracy of diagnosis ${ }^{[27,28]}$. Besides, haploinsufficiency of FIR mouse model promoted p53-dependent T-cell acute lymphoblastic leukemia progression ${ }^{[29]}$. SAP155, a subunit of the essential splicing factor $3 \mathrm{~B}$ (SF3B) subcomplex in the spliceosome, is required for proper P27Kip1 pre-mRNA splicing, and P27Kip1 arrests cells at G1 ${ }^{[30,31]}$. Moreover, spliceostatin A (SSA) or pladienolide, a natural SF3B inhibitor, markedly inhibited P27 expression by disrupting its pre-mRNA splicing with striking cell killing effects ${ }^{[32,33]}$. Further, FIR/PUF60 is required for transcriptional and post-transcriptional regulation of HBV pgRNA expression ${ }^{[34]}$. To develop novel diagnosis and therapy for hepatoma targeting FIR (PUF60)/FIR $\Delta$ exon2, small molecular chemical compounds against FIR $\Delta$ exon2 were screened among 2,3275 chemicals by natural product depository (NPDepo) array at RIKEN (Japan) to develop anti-cancer drugg ${ }^{[35-37]}$. Finally, small inhibitory chemicals against FIR/FIR $\Delta$ exon2 for hepatoma therapy will be discussed.

\section{METHODS}

\section{Cancer cell lines}

Human cervical SCCs (HeLa cells), gastric cancer cells (NUGC4), HLE cells and HLF cells were purchased from the American Type Culture Collection (https://www.atcc.org/). These cells were treated as described previously ${ }^{[18]}$. All cell lines were cultured in Dulbecco's modified Eagle medium supplemented with $10 \%$ fetal calf serum (FCS; Invitrogen, Tokyo, Japan) and 1\% penicillin-streptomycin, and they were cultured at $37{ }^{\circ} \mathrm{C}$ in a humidified atmosphere containing $5 \% \mathrm{CO}_{2}$.

\section{Protein extraction, western blotting and antibodies}

Culture medium was removed, and the cells were washed twice with cold $\left(4{ }^{\circ} \mathrm{C}\right)$ phosphate buffered saline (PBS), lysed with 1:20 $\beta$-mercaptoethanol and $2 \mathrm{x}$ sample buffer, and incubated at $100{ }^{\circ} \mathrm{C}$ for 5 -min. Whole-cell lysates were assayed for protein content (Bio-Rad, Hercules, CA, USA), and $10 \mu \mathrm{g}$ of proteins were separated 
by sodium dodecyl sulfate -poly- acrylamide gel electrophoresis on $7.5 \%$ or $10 \%-20 \%$ XV PANTERA gels and transferred onto polyvinylidene fluoride membranes using a tank transfer apparatus. The membranes were blocked with $0.5 \%$ skim milk in PBS overnight at $4{ }^{\circ} \mathrm{C}$. Antigens on the membranes were detected with enhanced chemiluminescence detection reagents (GE Healthcare UK Ltd., Buckinghamshire, UK). Membranes were incubated with primary antibodies [Supplementary Table 1] for $1 \mathrm{~h}$ at room temperature, followed by three 10 -min washes with $1 \mathrm{xPBS} / 0.01 \%$ Tween 20 . Membranes were then incubated with commercial secondary antibodies [Supplementary Table 1], followed by three 15-min washes with 1xPBS/0.01\% Tween 20. The primary mouse monoclonal antibody against FIR's C-terminus (6B4) was described previously ${ }^{[2]}$.

\section{Small molecular chemical compounds screening against FIR $\Delta$ exon2}

Small molecular chemical compounds against His-tagged FIR (His-FIR) and His-tagged FIR $\Delta$ exon2 were screened among 2,3275 chemicals of NPDepo at RIKEN as described previously ${ }^{[35-37]}$. Briefly, His-FIR $(645 \mu \mathrm{g} / \mathrm{mL})$ and FIR $\Delta$ exon $2(652 \mu \mathrm{g} / \mathrm{mL})$ proteins were applied to NPDepo array that contains 2,3275 natural chemical compounds. FIR $\Delta$ exon2 inhibitor BK697 was diluted in dimethyl sulfoxide (DMSO) at the concentration of $10 \mathrm{~mm}$, stored in room temperature, treated into HeLa and NUGC4 cell lines with different concentrations at different time intervals (see details in figure legends). Briefly, on day one, NUGC4 cells or HeLa cells were prepared in Iscove's modified Dulbecco's medium supplemented with 10\% FBS. On day two, candidate chemicals that inhibit FIR $\Delta$ exon2 protein were diluted in DMSO at the concentration of $10 \mathrm{~mm}$ and added as $10 \mathrm{~L}$ or $20 \mathrm{~L} /$ well/2 $\mathrm{mL}$ in the medium (final concentration in medium was $50 \mathrm{~mol} / \mathrm{L}$ and $100 \mathrm{~mol} / \mathrm{L}$ respectively) or added as $20 \mathrm{~L}$ or $60 \mathrm{~L} /$ well $/ 2 \mathrm{~mL}$ medium (final concentration in medium was $100 \mathrm{~mol} / \mathrm{L}$ and $300 \mathrm{~mol} / \mathrm{L}$ respectively). $100 \mathrm{~mol} / \mathrm{L}$ or $300 \mathrm{~mol} / \mathrm{L}$ of BK697 was treated to NUGC4 cells for $24 \mathrm{~h}, 50 \mathrm{~mol} / \mathrm{L}$ or $100 \mathrm{~mol} / \mathrm{L}$ of BK697 was treated to NUGC4 cells or HeLa cells for $6 \mathrm{~h}, 24 \mathrm{~h}$ and $48 \mathrm{~h}$ at $37^{\circ} \mathrm{C}$ in a $\mathrm{CO}_{2}$ incubator.

\section{Screening procedures of natural small molecular weight chemical compounds that potentially bind to FIR/FIRAexon2}

Small molecular weight chemical compounds potentially bound to FIR $\Delta$ exon2 were previously identified [Figure 1] from the NPDepo at RIKEN, which were a collection of the isolates from natural products, build by Dr Hiroyuki Osada (RIKEN, Japan) and his coworkers ${ }^{[35-37]}$.

\section{Procedure of in silico screening}

In the process for searching potent compounds, in silico screening was performed from the commercial chemical database. First, 1000 compounds were selected from the Namiki database that contains 5 million chemical entries, from the viewpoint of structural similarity to natural product that was identified to be bound to FIR in our previous work. Second, 125 compounds were extracted from the selected 1000 chemicals in terms of the electrostatic potential caused by the distribution of positive and negative charges. Finally, 5 compounds were purchased from a supplier for experimental assay. Namiki database (Namiki Shoji Co., Ltd., Tokyo, Japan, https://www.namiki-s.co.jp/english/) was a collection of commercially available screening-candidate chemicals.

\section{Display of three-dimensional structure of F-box and WD repeat domain-containing 7 (FBW7)}

To examine the possibility of molecular interaction between FBW7 and FIRs from structural viewpoint, two crystal structures were downloaded from protein data bank (PDB, https://www.rcsb.org/). One is a complex structure of FBW7 (PDB entry code: 2OVR). The other is the structure of an U2AF homology motif (UHM) domain in complex with UHM-ligand motif (ULM) of SAP155 (PDB entry code: 2PEH). Both crystal structures were visualized by PyMOL (DeLano, W. L.; The PyMOL Molecular Graphics System, Schrödinger, LLC).

MTS assay (Cell proliferation assay)

One day before the chemical treatment, cells were cultured in $100 \mu \mathrm{L}$ medium in flat-bottomed 96-well plates 


\begin{tabular}{|c|c|c|c|}
\hline IUPAC name & Structure & His-FIR & His-FIR $\Delta$ exon2 \\
\hline 1,4a-Dimethyl-2,3,4,4a,9,9a-hexahydro-1H-fluorene-1,9-dicarboxylic acid & & & $3+$ \\
\hline $\begin{array}{l}\text { 1-(1,4-Dimethyl-1H-pyrazol-3-yl)-2-(4-methoxy-6-methyl-5,6,7,8- } \\
\text { tetrahydro-[1,3]dioxolo[4,5-g]iso quinolin-5-yl)-ethanone }\end{array}$ & & $2+$ & \\
\hline $\begin{array}{l}\text { 1-[2-(1-Ethoxycarbonyl-3-phenyl-propylamino)-propionyl]-pyrrolidine-2- } \\
\text { carboxylic acid (compound with but-2-enedioic acid) }\end{array}$ & & & $3+$ \\
\hline $\begin{array}{l}\text { tert-Butyl-\{1-(4-methoxy-benzyloxymethyl)-4-[2-methoxy-6-(4- } \\
\text { methoxy-benzyloxymethyl)-5-methyl-tetr ahydro-pyran-2-yl]-2-methyl- } \\
\text { butoxy\}-diphenyl-silane }\end{array}$ & & $3+$ & \\
\hline $\begin{array}{l}\text { 5-Butyl-5-[2-(tert-butyl-diphenyl-silanyloxy)-1-triethylsilanyloxy-ethyl]- } \\
\text { dihydro-furan-2-one }\end{array}$ & & $3+$ & $3+$ \\
\hline $\begin{array}{l}\left.3^{\prime}, 5^{\prime}, 6^{\prime}, 7^{\prime}, 8^{\prime}, 8^{\prime} \text { a-hexahydro-6'-hydroxy-5', } 8^{\prime} \text { a-dimethyl-, ( } 5^{\prime} S, 6^{\prime} S, 8^{\prime} \text { aS }\right) \text { - } \\
\text { Spiro[1,3-dioxolane-2,1'(2'H)-naphthalene]-5'-acetamide }\end{array}$ & & & $2+$ \\
\hline 6-iodo-4-methylspiro[3,4-dihydro-1H-quinolin-1-ium-2,1'-cyclohexane ] & & $2+$ & \\
\hline $\begin{array}{l}\text { 3-(2,2-Dimethyl-tetrahydro-pyran-4-yl)-3-[2-(17-hydroxy-10,13- } \\
\text { dimethyl-1,2,6,7,8,9,10,11,12,13,14,15,16,17-tetradecahydro-cyclopenta[a] } \\
\text { phenanthren-3-ylideneaminooxy)-acetylamino]-propionic acid }\end{array}$ & & $3+$ & \\
\hline $\begin{array}{l}\text { 2-(\{4-[(2-tert-Butoxycarbonylamino-4-methyl-pentanoylamino)- } \\
\text { methyl]-cyclohexanecarbonyl\}-amino)-4-methylsulfanyl-butyric acid }\end{array}$ & & $1+$ & \\
\hline $\begin{array}{l}\text { 6-\{2-[3-(2-Methoxy-phenoxy)-2-methyl-4-oxo-4H-chromen-7-yloxy]- } \\
\text { acetylamino\}-hexanoic acid }\end{array}$ & & $3+$ & \\
\hline [2-(2-Benzyloxycarbonylamino-acetylamino)-acetylamino]-acetic acid & & $3+$ & \\
\hline 3,7-Bis-furan-2-ylmethylene-bicyclo[3.3.1]nonane-2,6-dione & & $1+$ & \\
\hline
\end{tabular}

Figure1. Structures of small molecular weight chemicals that were interacted with His-tagged far upstream element-binding proteininteracting repressor (His-FIR) or His-FIRAexon2 screened by natural product depository (NPDepo) (RIKEN, JPN). 3+: strong interaction; 2+: moderate interaction; 1+: weak interaction; IUPAC: International Union of Pure and Applied Chemistry

so that the cells will reach $40 \%-80 \%$ confluent at the time of chemical treatment. After $24 \mathrm{~h}$ incubation at $37^{\circ} \mathrm{C} / 5 \% \mathrm{CO}_{2}$, cells were treated with chemicals. After $24 \mathrm{~h}$ incubation at $37^{\circ} \mathrm{C}$, CellTiter $96^{\circ}$ AQueous One Solution Reagent (Promega, Madison, WI, USA) was added to each well according to the manufacturer's instructions. Briefly, CellTiter $96^{\circ}$ AQueous One Solution Reagent was warmed up and added to each well (20 L/well), incubated for $1 \mathrm{~h}$ at $37^{\circ} \mathrm{C}$. Then, $10 \% \mathrm{SDS}$ solution was added to each well (25 L/well). Cell viability was determined by measuring the absorbance at $490 \mathrm{~nm}$ using a 550 Bio-Rad plate reader. All samples are tested in duplicate, absorbencies were tested 3 times. Same volume of DMSO was used as negative control. Same volume of $3 \% \mathrm{H}_{2} \mathrm{O}_{2}$ was used as positive control. 


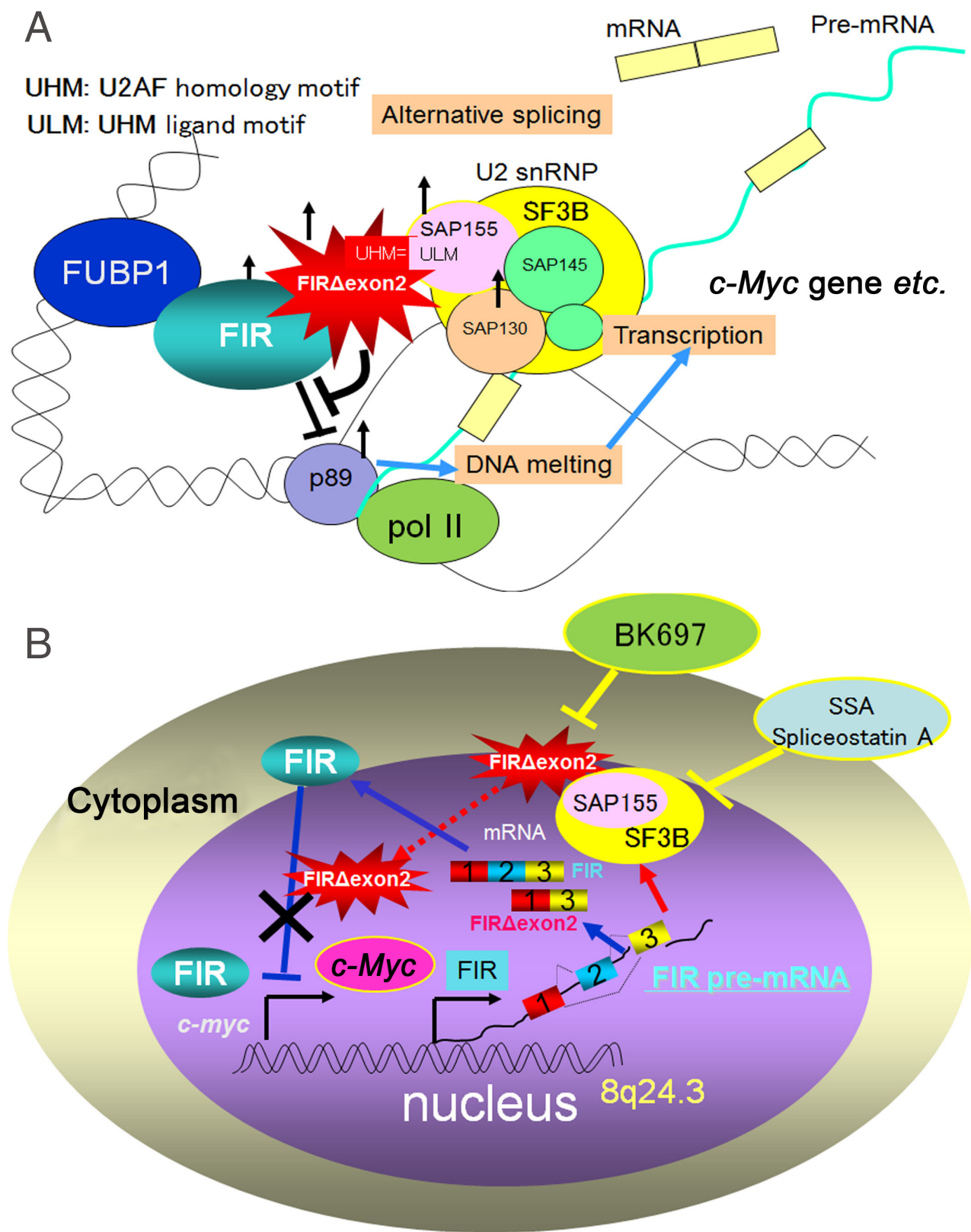

Figure 2. (A) Elevated expression of $c-M y c$ has been detected in a broad range of human cancers, indicating a key role for this oncogene in tumor development. Far upstream element-binding protein-interacting repressor (FIR) gen and c-Myc gene locates at 8q24.3. An interaction between FIR (FBP interacting repressor) and transcriptional factor IIH helicase was found to repress $c-M y c$ transcription and so might be important for suppressing tumor formation. FIR is alternatively spliced in colorectal cancer lacking the transcriptional repression domain within exon 2 (FIR $\Delta$ exon2) that inhibit FIR as a dominant negative form of FIR. FIR $\Delta$ exon2 potently forms a heterodimer with FIR and thus FIR $\Delta$ exon2 interferes with FIR to bind to far upstream element of $c-M y c$ promoter where FIR binds. FIR and FIR $\Delta$ exon2 form a homo- or hetero-dimer, which makes a complex with SAP155. SAP155 is a subunit of the essential splicing factor 3B (SF3B) subcomplex in the spliceosome. The interaction between SAP155 and FIR/FIR $\Delta$ exon2 potentially integrated cell cycle progression and c-Myc transcription through P89 suppression; (B) FIR/FIRAexon2/SAP155 interaction is pivotal for cancer development and differentiation and is thus a potent target for cancer screening and treatment. These results strongly suggest that FIR $\Delta$ exon2 antagonized FIR in c-Myc transcriptional suppression and simultaneously interferes with SF3B in splicing during tumor progression. Importantly, Spliceostatin A that is a strong chemical inhibitor of SF3B resulted in c-Myc overexpression probably due to the FIR downregulation. FIR: FUBP1-interacting repressor 


\section{RESULTS}

\section{Mechanism in carcinogenesis of FIR/FIRAexon2/PUF60 as a target for cancer diagnosis and therapy}

Previous studies revealed that FUBP1, FIR (PUF60)/FIR $\triangle$ exon2, SAP155, and SAP130 were over expressed in hepatocellular carcinoma (HCC) tissue ${ }^{[18]}$. Additionally, FIR/FIR $\Delta$ exon2 mRNA levels were increased in HCC $^{[38]}$. Recent studies have been revealed regarding direct protein interactions between UHM family and ULM family [Supplementary Figure 1] ${ }^{[39-41]}$. SAP155/SAP145/SAP130 subunits consist of SF3B complex and UHM of FIR/ PUF60 directly binds to ULM of SAP155 (SF3B1) [Supplementary Figure 1A-C] $]^{[32,41,42]}$. Further, FUBP1, FIR (PUF60)/FIR Dexon2, SAP155, and SAP130 were over expressed in hepatitis C virus (HCV)-related HCC tissue and FIR (PUF60)/FIR $\Delta$ exon2 reflects DNA damage [Supplementary Figure 1D] ${ }^{[18]}$. Bleomycin-induced DNA damage decreased SAP155 and significantly increased FIR/FIR $\triangle$ exon2 mRNA expression as well as the FIR $\Delta$ exon2: FIR ratio in hepatoblastoma (HLE and HLF) cells $^{[18]}$. Therefore, FUBP1/FIR (PUF60)/FIR $\Delta$ exon2 proteins, mRNAs and/or autoantibodies against these peptides are highly possible biomarker candidates for hepatoma diagnosis. Anti-FIR/FIR $\Delta$ exon2 autoantibodies were detected in several gastrointestinal cancers $^{[27,28]}$. Anti-FIR/FIR $\Delta$ exon2 autoantibodies in the sera of HCC patients are now under investigation. Given FIR $\Delta$ exon2 is a dominant negative regulator of FIR/PUF60, FIR $\Delta$ exon2 inhibition is an advantageous target for cell growth suppression [Figure 2A]. Inhibition of SF3B (SAP155) by siRNA or SSA resulted in c-Myc overexpression possibly due to the FIR downregulation [Figure $2 \mathrm{~B}]^{[1]}$. Knockdown of SAP155 or FIR was used to investigate their reciprocal influence on each other and on $c-M y c$ transcription, pre-mRNA splicing, and protein expression ${ }^{[31]}$. FIR and FIR $\Delta$ exon2 were co-immunoprecipitated with SAP155 $5^{[31]}$. UHM of FIR/PUF60 at carboxyl-terminus directly binds to W (Typ) D (Asp)-domain of SF3B1 (SAP155) as ULM ${ }^{[42,43]}$. The tight FIR/FIR $\triangle$ exon2-SAP155 interaction disables established FIR and SAP155 functions disturbing the synthesis of normally spliced FIR mRNA. FIR $\Delta$ exon2 potently forms a heterodimer with FIR and thus FIR $\Delta$ exon2 interferes with FIR to bind to FUSE [Supplementary Figure 1D]. These results strongly suggest that FIR $\Delta$ exon2 antagonized FIR in $c-M y c$ transcriptional suppression and simultaneously interferes with SF3B in splicing during tumor progression. Therefore, both common and discriminating recognition elements in the UHMULM binding interface provide a rationale for a structural basis for specific UHM-ULM interactions and a platform of intermolecular interactions governing disease-related AS in eukaryotic cells ${ }^{[40]}$. For instance, SF3B1 (SAP155)/FIR/PUF60 complex is a target of cancer therapy. In these scenarios, low molecular weight artificial chemical, BK697, was synthesized by in silico screening that targets FIR $\Delta$ exon2 in this study [Figure 2B]. Small molecular chemical compounds against FIR $\Delta$ exon2 were screened among 23,275 chemicals of NPDepo by Dr Hiroyuki Osada and his colleagues (RIKEN, Wako, Saitama, Japan) to develop cancer therapy [Figure 1]. Nine small molecular chemicals were identified by NPDepo screening against FIR and four chemicals against FIR $\Delta$ exon2 as candidates of interacting chemicals [Figure 1].

\section{The interaction of FIRDexon2 and WD-like domain of FBW7 and in silico screening of small molecular chemical compounds against FIR/FIRAexon2 for cancer therapy}

FBW7 frequently is mutated in hematopoietic tumors ${ }^{[44]}$. FBW7 is a member of the Skp1-Cull-F-box type ubiquitin ligase complex and is involved in degradation of various growth-related proteins, Notch1, c-Myc, c-Jun, and cyclin E via the proteasome system ${ }^{[4]}$, indicating FBW7 is a tumor suppressor in cancer development and progression ${ }^{[45]}$. Remarkably, three-dimensional structure analysis revealed the hypothetical inhibitory mechanism of FBW7 function by FIR/FIR $\Delta$ exon2 [Figure 3]. The binding structure between SAP155 (SF3B1) and one of the splicing factors containing UHM, SPF45, was already clarified by X-ray crystal analysis (PDB code: $\# 2 \mathrm{PEH}$ ) [Figure $3 \mathrm{~A}$ and $\mathrm{B}$ ]. In the $2 \mathrm{PEH}$ structure, the crystal unit cell contains two SPF45 recombinant proteins (a.a. 301-401) and two SAP155 partial peptides (a.a. 333-342). SPF45 has an amino sequence of LNGRYFGGRVVKA [Figure 3A] and similar sequences are commonly seen at the C-terminal domains of FIR and U2AF65 [Figure 3B]. According to the crystal structure, $2 \mathrm{PEH}, \mathrm{SPF} 45$ makes a strong interaction with a WD part of SAP155 at the domain of the above-mentioned conserved sequence. 
A

Similar amino sequences at the C-terminal sides of SPF45, FIR, and U2AF64

\begin{tabular}{|ll|}
\hline & ... . . . \\
SPF45 (aa.372-384) & LNGRYFGGRVVKA \\
FIR-wild (aa.505-517) & LNGRWFAGRKVAA \\
U2AF65 (aa.449-510) & LTGRKFANRVVVT \\
\hline
\end{tabular}

C-terminal similar sequence of SPF45 LNGRYFGGRVVKA

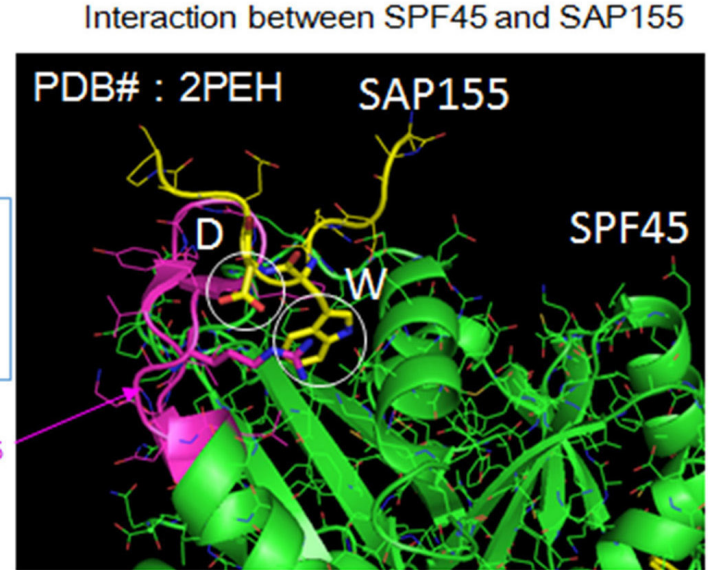

Contact of $\operatorname{Trp}(\mathrm{W})$ and $\mathrm{Asp}(\mathrm{D})$ of with

$\operatorname{Arg}(R)$ of the C-terminal sequence of SAP155

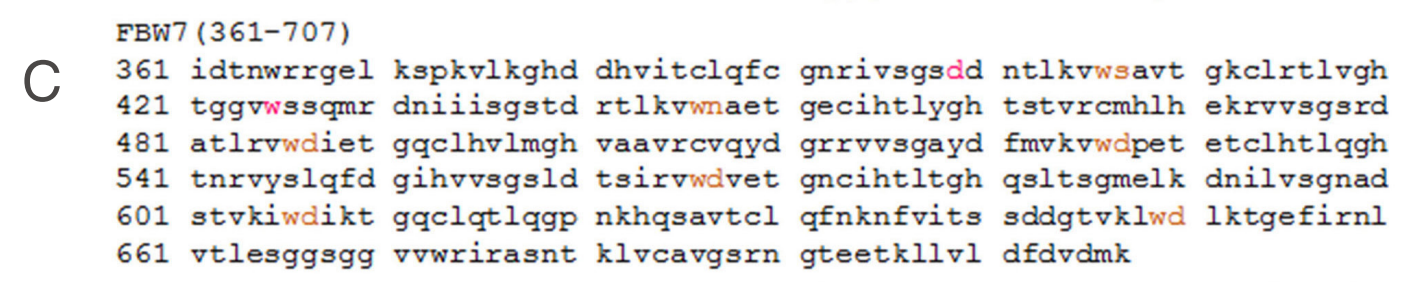

Degron pocket of FBW7

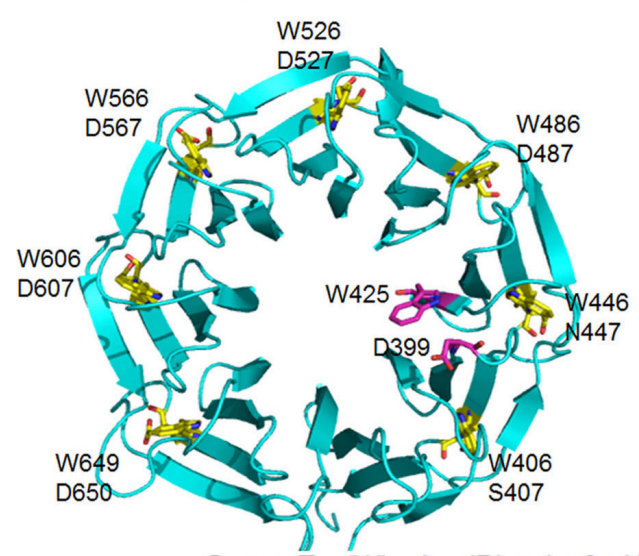

Binding structure between FBW7 and its recognizing phosphorylated peptide

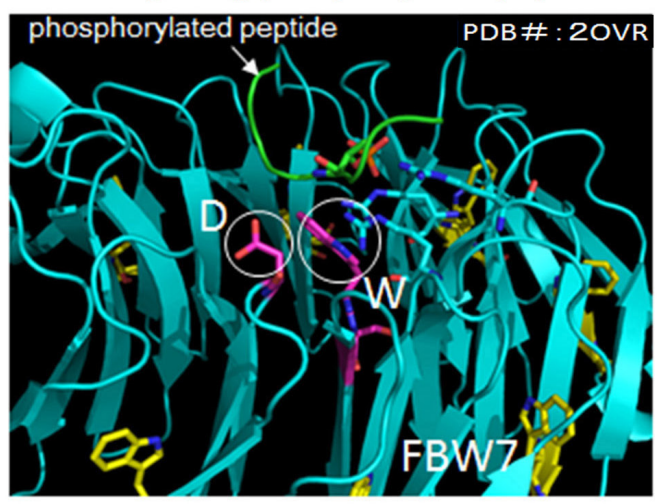

Seven Trp(W) - Asp(D) pairs for WD-repeat motif (yellow) an extra WD residues at the center of the pocket (magenta)

Figure 3. (A) The binding structure between splicing factor $3 B(S F 3 B)$ and one of the splicing factors containing U2AF homology motif, SPF45, was already clarified by X-ray crystal analysis (protein data base code: \#2PEH). In the 2PEH structure, the crystal unit cell contains two SPF45 recombinant proteins (a.a. 301-401) and two SF3B partial peptides (a.a. 333-342); (B) SPF45 has an amino sequence of LNGRYFGGRVVKA and similar sequences are commonly seen at the C-terminal domains of far upstream element-binding proteininteracting repressor (FIR) and U2AF65. According to the crystal structure, 2PEH, SPF45 makes a strong interaction with a WD part of SF3B at the domain of the above-mentioned conserved sequence. FIR and U2AF65 are also expected to interact with SF3B through the domains with the similar amino sequences; (C) F-box and WD repeat domain-containing 7 (FBW7) has many WD motifs and most of the motifs are involved in the conformational stabilization of the WD-repeated domain. Although those WD motifs are not related to the ligand recognition of FBW7, there is an extra pair of W425 and D399 at the center of the WD-repeated domain. Most of the ligands of FBW7 are the amino peptides that include phosphorylated Thr or Ser, because three Arg residues are located at the center of the WDrepeated domain and hold the negatively charged peptides by phosphorylation. The extra pair of $W$ and $D$ at the WD-repeated domain will not be involved in the ligand recognition of the phosphorylated peptides, but the WD pair can interact with the peptide with the above-mentioned conserved sequence from the structural viewpoint. Hence, FIR may be bound to the WD-repeated domain and block the function of FBW7. FIR: FUBP1-interacting repressor; WD: W (Typ) D (Asp) 
FIR and U2AF65 are also expected to interact with SAP155 through the domains with the similar amino sequences. FBW7 has many WD motifs and most of the motifs are involved in the conformational stabilization of the WD-repeated domain. Although those WD motifs are not related to the ligand recognition of FBW7, there is an extra pair of W425 and D399 at the center of the WD-repeated domain. Most of the ligands of FBW7 are the amino peptides that include phosphorylated Thr or Ser, because three Arg residues are located at the center of the WD-repeated domain and hold the negatively charged peptides by phosphorylation [Figure $3 \mathrm{C}$ ]. The extra pair of $\mathrm{W}$ and $\mathrm{D}$ at the WD-repeated domain will not be involved in the ligand recognition of the phosphorylated peptides, but the WD pair can interact with the peptide with the above-mentioned conserved sequence from the structural viewpoint. Hence, FIR may be bound to the WD-repeated domain and block the function of FBW7 [Figure 3C]. Together, latent disturbance of FBW7 by FIR/FIR $\Delta$ exon2/PUF60 in cancers inhibit degradation of substrate proteins.

FBW7 expression was decreased significantly in esophageal squamous cell carcinoma (ESCC) ${ }^{[46]}$. Conversely, FIR and FIR $\Delta$ exon2 were overexpressed in ESCC. Especially, the knockdown of SAP155 (SF3B1), a splicing factor required for proper AS of FIR pre-mRNA, decreased cyclin $\mathrm{E}^{[46]}$. Therefore, disturbed AS of FIR generated FIR/FIR $\triangle$ exon2 with cyclin E overexpression in esophageal cancers, indicating that SAP155 siRNA potentially rescued FBW7 function by reducing expression of FIR and/or FIR $\Delta$ exon $2^{[46]}$. A novel low molecular weight chemical, BK697, with WD-like domain structure that inhibits FIR/FIR $\Delta$ exon2 [Figures $2 \mathrm{~B}$ and 3$]^{[46]}$, indicating simultaneous downregulation of FBW7 and E-cadherin accompanied with disturbed splicing of FIR is required for migration [or epithelial-mesenchymal transition (EMT)] in cancers.

\section{Cell growth inhibition by in silico-screened compounds against FIR $\Delta$ exon2 protein}

A small molecular weight chemical that has WD-like motif was identified by NPDepo screening [Figure 1-top, Figure 4-(A), (C)]. From computer screening to search synthesized chemicals that mimicking the structure of the identified compound using Namiki database (Namiki Shoji Co., Ltd., Tokyo, Japan) that was composed of commercially available chemicals [Figure 4-(B), (B')]. Recently, FIR $\Delta$ exon2 was suggested to be potentially bound to the substrate-binding degron pocket of FBW7. Since the substrate-binding degron pocket of FBW7 contains a unique structure of Trp (W) and Asp (D) combination (WD motif) and the WD motif is expected to interact with FIR $\Delta$ exon2 [Figure 3]. Actually, chemical skeleton of the two synthesized compounds were regarded as a WD mimicking form [Figure $4(\mathrm{~A})-(\mathrm{D})]^{[46]}$. All of the compounds bear a chemical skeleton of aromatic ring connected to carboxyl group with a short linker. Hence, these compounds are analogues of WD motif of FBW7 [Figure 4]. From these chemical structural findings of WD mimicking form, several compounds were selected from the chemicals that have been synthesized in our previous studies [Figure 4$]^{[46-49]}$. Synthesized compounds were intended to inhibit FIR $\Delta$ exon2 protein function.

\section{Low molecular weight artificial chemical, BK697, that inhibits FIRAexon2 protein function suppressed tumor cell growth}

Affiliated small molecular weight chemicals that have WD-like motif screened by NPDepo [Figure 5A, square]. Based on the computer screening, lots of similar chemicals were designed and seven compounds were selected for treating with HLE and HLF cells to examine cell growth inhibition [Figure 5A, arrows]. Expectedly, BK697 effectively suppressed hepatoblastoma cells, HLE and HLF cells [Figure 5B]. BK697 suppressed FIR/FIR $\triangle$ exon2 expression on dose-dependent manner in NUGC4 cells [Figure 5C, left] and HeLa cells [Figure 5C, right]. Particularly, FIR/PUF60 is required for HBV cccDNA replication ${ }^{[34]}$, BK697 is a promising candidate for hepatoma treatment by suppressing HBV cccDNA. Previously, FIR has been revealed to contribute to the splicing of PKM1 to PKM2 in mice thymic lymphoma using six-plex tandem mass tag quantitative proteomic analysis in mice model [Table 1] ${ }^{[50,51]}$. SAP155 (SF3B1) and FIR/PUF60 are required for E-cadherin expression through engaging in its mRNA editing that is pivotal for cell-cell adhesion or EMT ${ }^{[52]}$. Together, BK697 suppressed cell growth through interfering FIR $\triangle$ exon2 with binding to analogues of WD-like motif of FBW7 


\title{
Procedure of in slico screening
}

\author{
first screening \\ OpenEye (ROCS) \\ tanimoto coeff. $>0.75$
}

\section{Chemical Database \\ (Namiki : 5 million entry)}

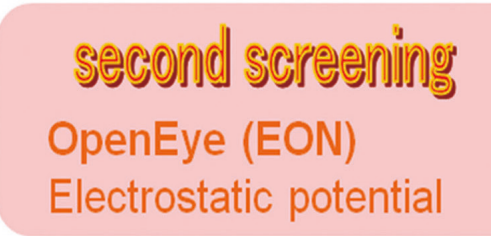

third screening

Visual Inspection

(A)<smiles>C[C@]12CCC[C@@](C)(C(=O)O)[C@H]1Cc1ccccc12</smiles>

(C)

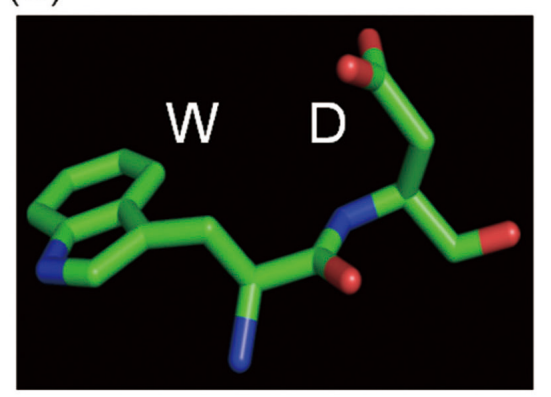

(B)<smiles>Cn1c(O)c(CC(=O)O)c(=O)c2ccccc21</smiles>

(B')<smiles>COc1cccc2c(O)c(CC(=O)O)ccc12</smiles>

(D)

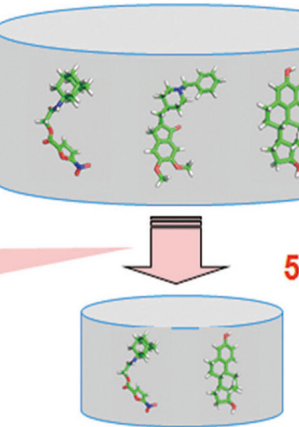

\section{(n)}


Table 1. Summaries of studies in far-upstream element-binding protein (FUBP1)/far upstream element-binding proteininteracting repressor (FIR)/FIRDexon2/poly (U)-binding-splicing factor (PUF60) system related to human diseases

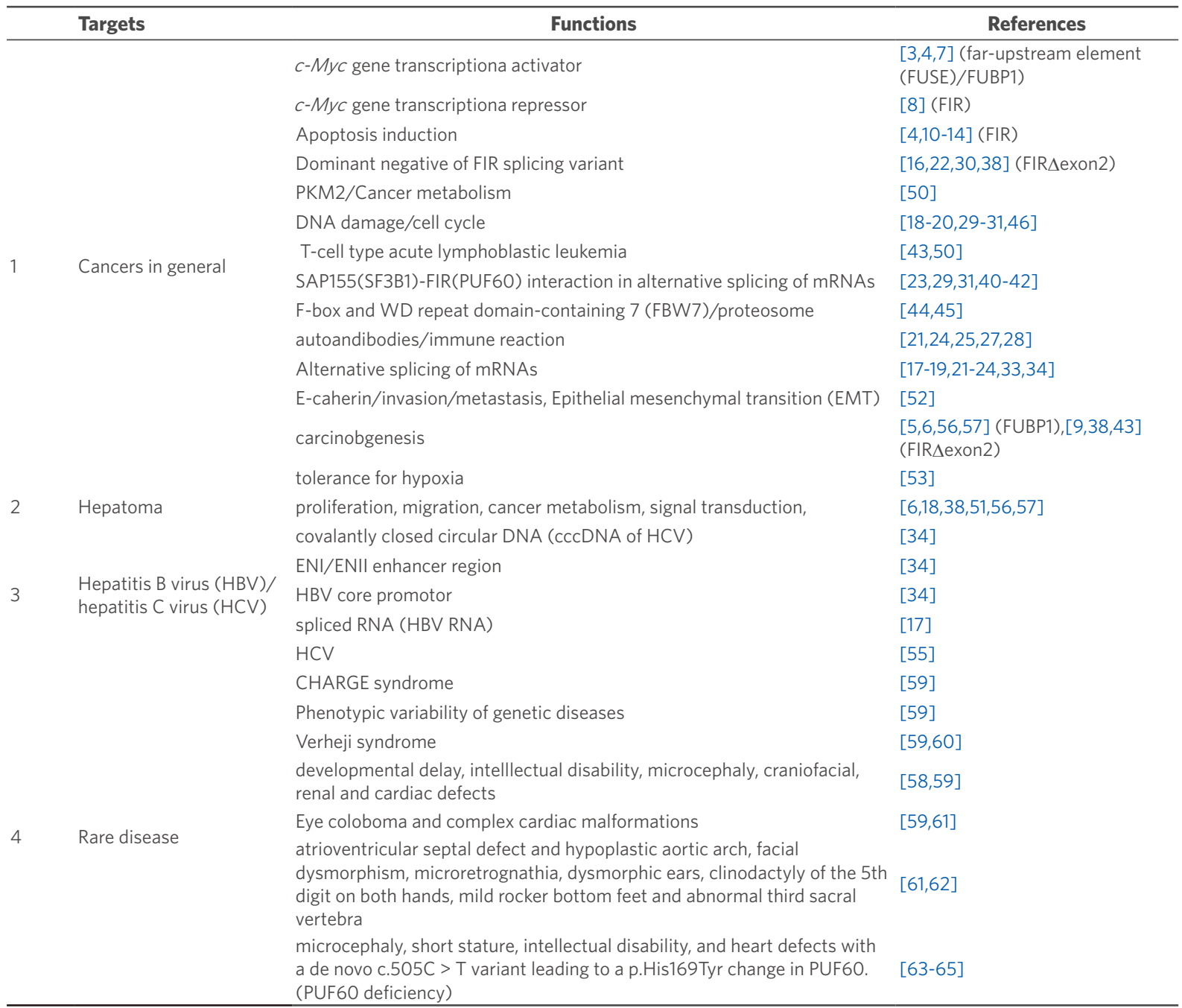

in the degron pocket (W425 D399 in the 3D-structure) [Figure 3]. Together, simultaneous downregulation of FBW7 and E-cadherin is potentially pivotal for invasion or metastasis of cancers through EMT and may also contribute to therapeutic target for cancers. Clinically, BK697 and its derivatives are potential candidate anticancer drugs for cancers targeting FBW7 and E-cadherin suppression.

\section{DISCUSSION}

This study demonstrated that FIR strongly repressed endogenous c-Myc transcription and induced apoptosis. Most importantly, a splicing variant of FIR, FIR $\Delta$ exon2, found frequently in human primary colorectal cancer tissue, not only lacked the c-Myc-suppressing and apoptosis-inducing action of FIR, but prevented normal FIR from performing these activities. Thus FIR $\Delta$ exon 2 may contribute to tumor progression by enabling higher levels of c-Myc expression and greater resistance to apoptosis in tumors than in normal cell [Figure 2A]. The value of FIR and/or FIR $\Delta$ exon2 detection for cancer diagnosis is under investigation. Recently, PUF60, another FIR splicing variant having exon 5, directly binds to splicing factor SF3B1 with $\mathrm{UHM}^{[39]}$ and inhibition of SF3B (SAP155 is a subunit of SF3B) by natural chemicals demonstrated strong antitumor effect [Figure 2B] ${ }^{[32,33]}$. Hypoxia leads to AS of FIR/PUF60 and in PC3 prostate cancer cells ${ }^{[53]}$. Given the central role of c-Myc in the development of many cancers, and inhibition of splicing function of PUF60 (or FIR itself) with SF3B indicates strong antitumor activity, one route to the development of 
A

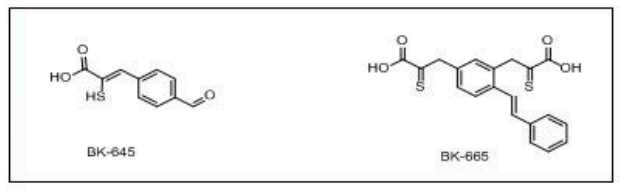

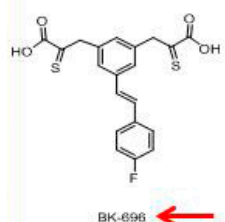<smiles>[Mg][TeH]</smiles>

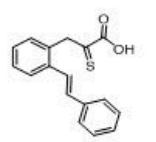<smiles>O=C(O)C1CCCCC1C(=O)O</smiles>

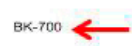

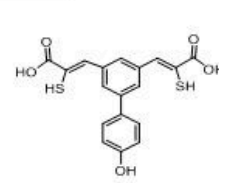

o.me $\leftarrow$

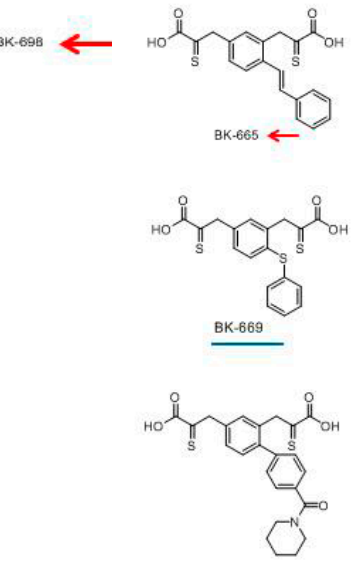

Bk-684

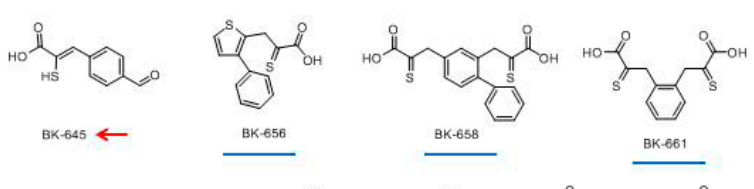

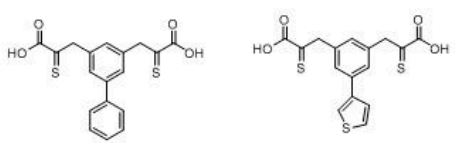

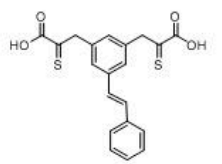

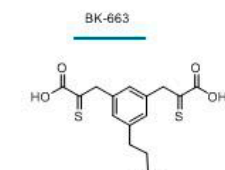

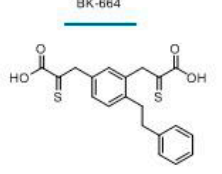

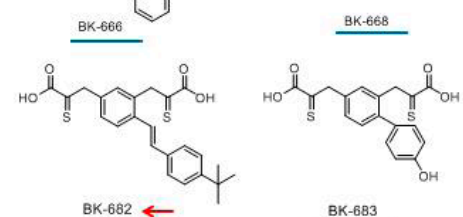

${ }_{B \mathrm{BK}-682} \leftarrow \quad$ BK-683

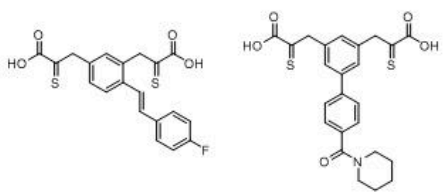

$\underline{\text { BK-685 }}$

BK.666

B

MTS Assay (Cell confluency was $80 \%$ at time of drug treatment)

HLE cells

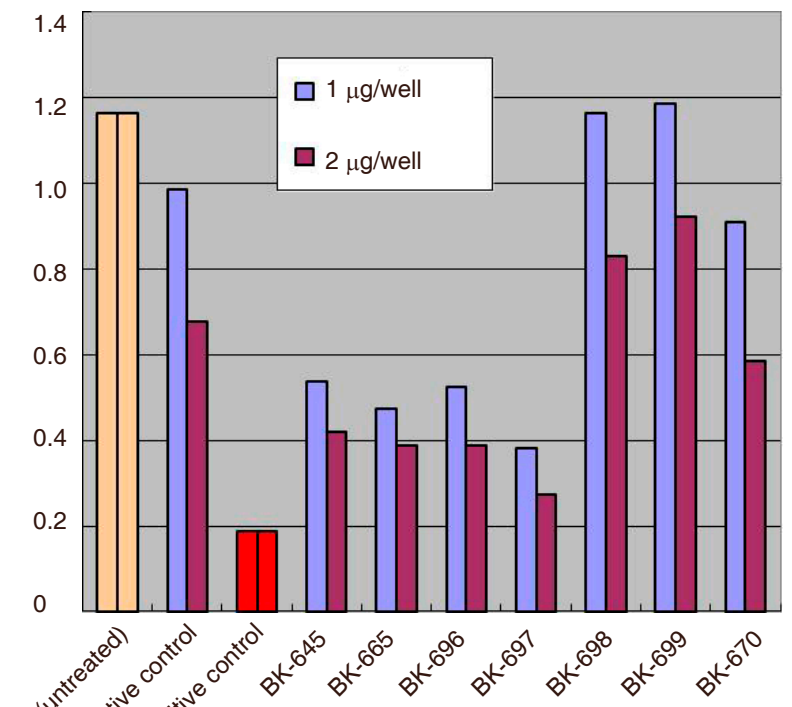

HLF cells

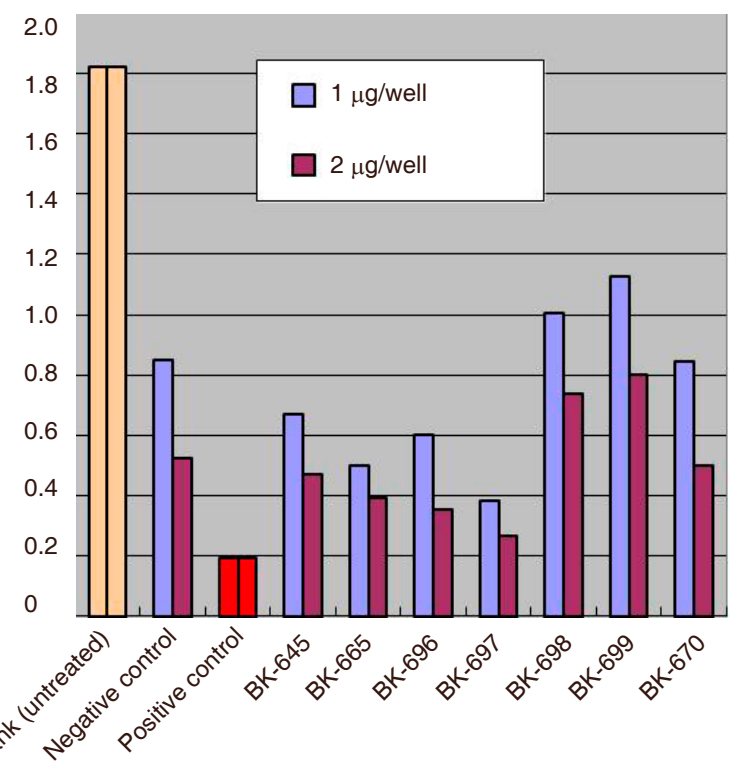



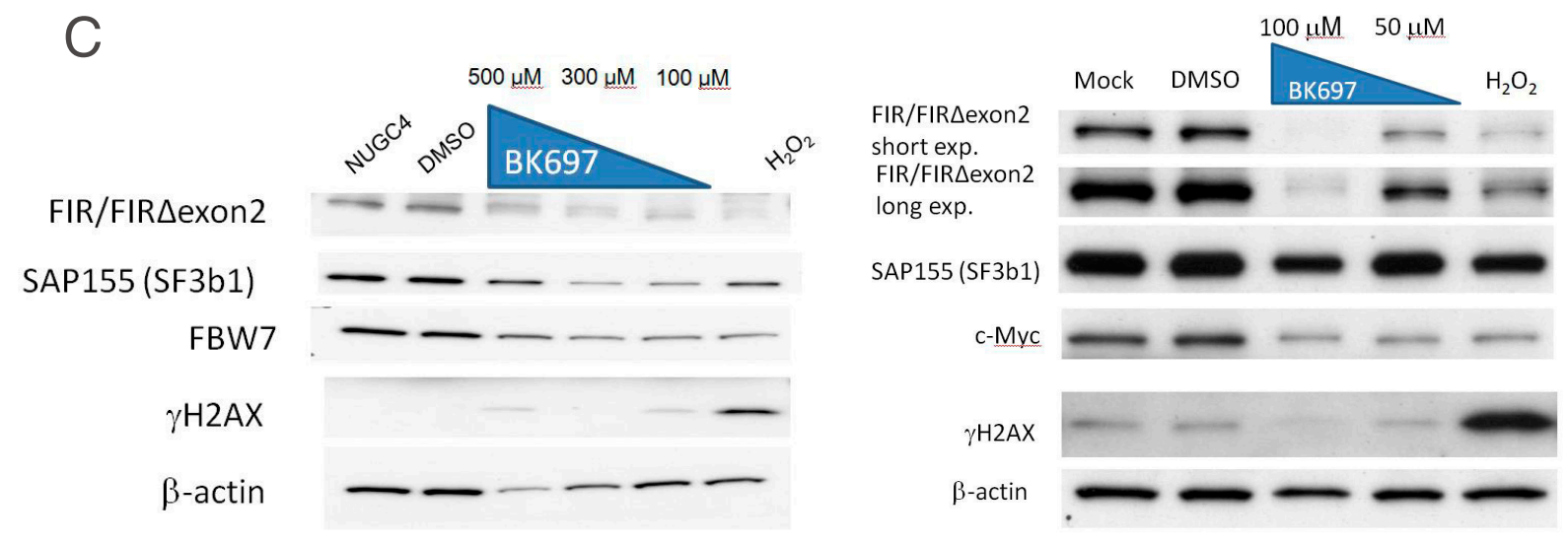

Figure 5. BK697 inhibit far upstream element-binding protein-interacting repressor $\Delta$ exon2 (FIR $\Delta$ exon2) that is considered as a dominant negative of FIR. (A) From computer screening to search synthesized chemicals that mimicking the structure of the identified compound using Namiki database (Namiki Shoji Co., Ltd., Tokyo, Japan) that was composed of commercially available chemicals after natural product depository array at RIKEN (Japan). Affiliated chemicals were screened and indicated in the square (square). Based on the computer screening, lots of similar chemicals were designed and seven compounds were selected for treating with HLE and HLF cells to examine cell growth inhibition (arrows); (B) BK697 effectively suppressed hepatoblastoma cells, HLE and HLF cells. BK697 effectively suppressed hepatoblastoma cells, HLE and HLF cells by MTS assay (see materials and methods). Small molecular weight indicated arrows (A) were examined the cell growth suppression in HLE and HLF cells. All samples are tested in duplicate, absorbencies were tested 3 times. Same volume of DMSO was used as negative control. Same volume of $3 \% \mathrm{H}_{2} \mathrm{O}_{2}$ was used as positive control; (C) BK697 suppressed FIR/FIR $\Delta$ exon2 expression on dose-dependent manner in gastric cancer cells (left) and HeLa cells (right). Note SAP155 (SF3B1) was also suppressed by BK697 along with FIR/FIR Lexon2 expression. H2AX is a marker of DNA damage. FIR: FUBP1-interacting repressor; HLE: hepatoblastoma cell line; MTS: 3-(4,5-dimethylthiazol-2-yl)-5-(3-carboxymethoxyphenyl)-2-(4-sulfophenyl)-2Htetrazolium, inner salt; DMSO: dimethyl sulfoxide

cancer therapies directed against c-Myc and splicing of SF3B inhibition may go through FIR and its splicing variants. In this study, BK697 has been screened to target SAP155-binding FIR $\Delta$ exon2 for cancer therapy [Figure $2 \mathrm{~B}$ ]. According to recent cancer gene therapy, adenovirus-mediated (Ad) TP53 gene transfer is frequently used, together with cis-dichloro-diammineplatinum administration or ionizing radiation ${ }^{[1,10]}$. As for Ad-FIR or Sendai virus-FIR vector, the transduction efficiency showed that the efficacy in preclinical trials and combination treatment with standard chemoradiation and Ad-FIR/Sendai-FIR gene therapy may be an attractive modality in the future ${ }^{[10-14]}$.

HBV has a small (3.2 kb), partially-double stranded, relaxed-circular DNA genome that encodes four overlapping open reading frames $(\mathrm{ORFs})^{[54]}$. The genomic transcripts from these overlapping four ORFs act mRNAs for precore, core and polymerase. The genomic transcript that encodes both core and polymerase is multifunctional and referred to as $\mathrm{pgRNA}^{[54]}$. The core protein binds to HBV covalently closed circular DNA (cccDNA). The cccDNA forms a minichromosome in the nucleus of the hepatocyte ${ }^{[54]}$. Recent nucleoside analogues and interferons treatment for HBV-positive patients do not achieve complete clearance of viral genome cccDNA in the nucleus [Figure 6]. To our interest, PUF60 was identified as a versatile regulator of transcriptional and post-transcriptional steps in expression of $\mathrm{HBV} 3.5 \mathrm{~kb}$, precore plus pgRNA ${ }^{[34]}$. This is the first to identify a host cell factor (protein) involved in not only positively regulating viral gene expression but also negative regulation of the same viral life cycle $^{[34]}$. Therefore, FIR/PUF60 is also a novel promising target to inhibit HBV cccDNA transcription as well as interfering FBW7 function [Figure 6]. Given the FIR/ PUF60 is required for HBV cccDNA replication ${ }^{[34]}$ and novel small molecular weight chemicals including BK697 that suppresses FIR/PUF60 expression [Figure 5C], those chemicals have advantage to eliminate $\mathrm{HBV}$ cccDNA than other strategies as recent nucleoside analogues and interferons treatment. Further, the amino terminus of FIR was necessary to repress transcription from the c-Myc promoter by suppressing FUBP1, FUBP [Figures 2 and 6] ${ }^{[22]}$. FUBP1/FIR(PUF60)/TFIIH system FIR suppresses endogenous c-Myc 


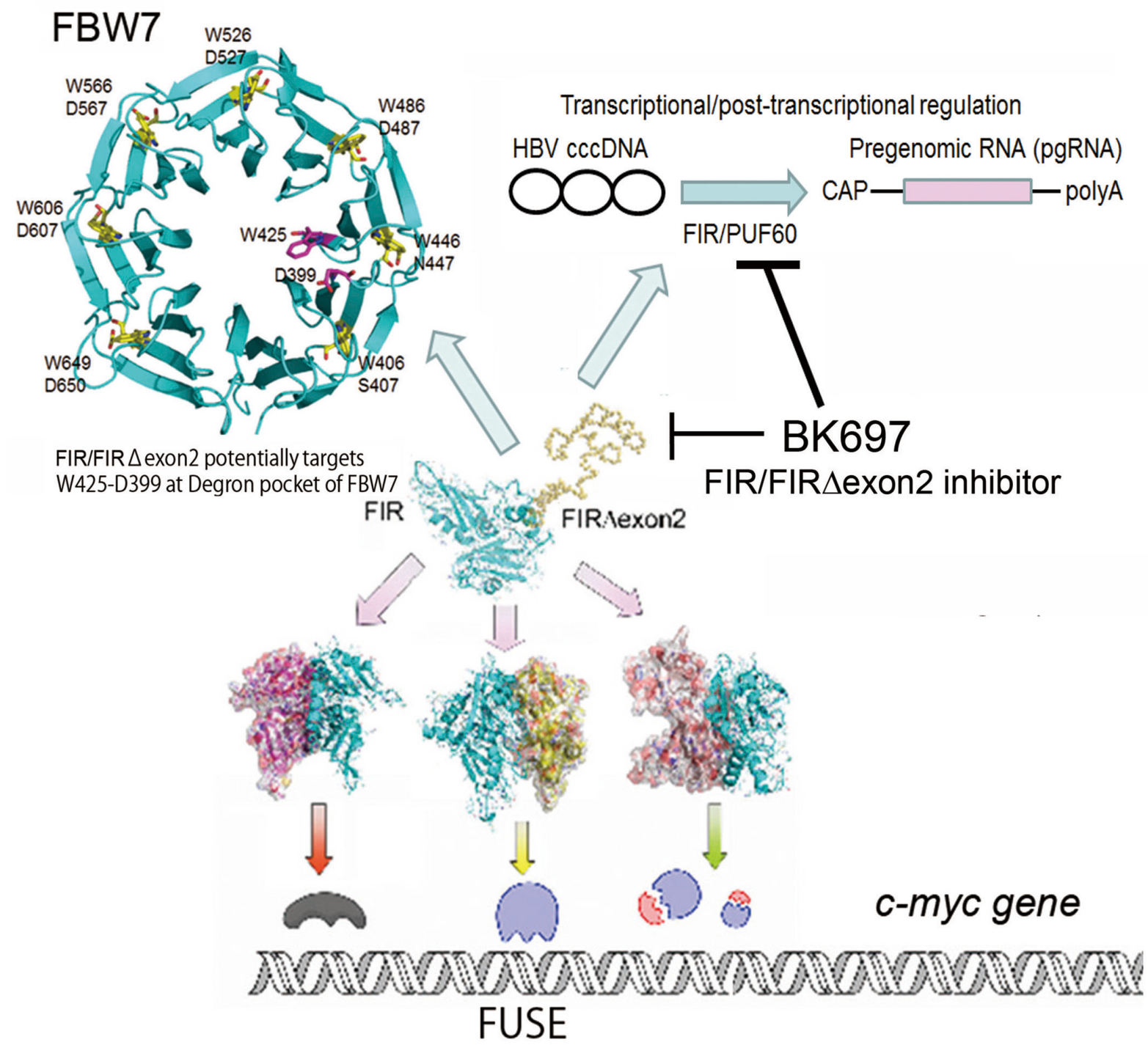

Figure 6. Far upstream element-binding protein-interacting repressor $\triangle$ exon2 (FIR $\Delta$ exon2) inhibitor BK697 inhibited the growth of the HeLa cells. BK697 is a candidate anticancer drug for inhibiting hepatitis B virus (HBV) replication for hepatoma therapy. FIR/poly (U)binding-splicing factor (PUF60) has three different functions. (1) A c-Myc gene transcriptional repressor; (2) disturbance of substrate proteins degradation through competing with the access to degron pocket of F-box and WD repeat domain-containing 7 (FBW7); and (3) transcriptional/posttranscriptional regulation of HBV covalently closed circular DNA (cccDNA). Targeting FIR/PUF60 is a promising strategy for cancer therapy. FIR: FUBP1-interacting repressor; WD: W (Typ) D (Asp)

at transcriptional level by its amino terminal domain [Figure 2A]. Further, FUBP1 facilitates persistence HCV replication in HCC cells ${ }^{[55]}$. FUBP1 as well as FIR (PUF60) is required for tumor growth in $\mathrm{HCC}^{[38,56,57]}$. Additionally, FUBP1/FIR (PUF60)/TFIIH complex potentially support the growth of hepatoma by c-Myc gene transcriptional activation and HCV replication [Table 1]. Further, FUBP1/FIR/FIR $\Delta$ exon2/PUF60 are expressed in HCC tissue and less expressed in the normal tissue in developed cells ${ }^{[18,38]}$. Therefore, small molecular weight chemicals targeting FUBP1/FIR/FIR $\Delta$ exon2/PUF60 system are expected to be harmless.

Recently, FIR/PUF60 and human rare disease are reported [Table 1]. CHARGE syndrome shows an autosomaldominant, multiple congenital anomaly symptom characterized by vision and hearing loss, congenital heart disease, and malformations of craniofacial and others ${ }^{[58]}$. Pathogenic variants in CHD7 of CHARGE 
syndrome patients were present in 15 of 28 individuals (53.6\%), whereas 4 (14.3\%) individuals had other pathogenic variants such as RERE, KMT2D, EP300, or FIR/PUF60 ${ }^{[59]}$. A two base pair deletion was identified in the PUF60 gene, which is one of three genes in the critical region of the 8q24.3 microdeletion syndrome (Verheij syndrome) that shows intellectual disability ${ }^{[60]}$. In 2013, patients with microdeletions of chromosome 8q24.3 including FIR/PUF60 were found to have developmental delay, microcephaly, craniofacial, renal and cardiac defects were found in six patients with variants in FIR/PUF60 ${ }^{[6]]}$. Eye coloboma and complex cardiac malformations belong to the clinical spectrum of PUF60 variants ${ }^{[62,63]}$. The fetus presented atrioventricular septal defect and hypoplastic aortic arch, facial dysmorphism, microretrognathia, dysmorphic ears, clinodactyly of the 5th digit on both hands, mild rocker bottom feet and abnormal third sacral vertebra ${ }^{[64]}$. An individual was reported with microcephaly, short stature, intellectual disability, and heart defects with a de novo c.505C > T variant leading to a p.His169Tyr change in PUF60 ${ }^{[65]}$. The publications that show the direct interaction between FIR/PUF60 deficiency and human disease have been accumulating [Table 1]. FIR/PUF60 deficiency-associated amino-acid substitutions, even within a single RNA recognition motif, altered selection of competing 3' splice sites (3'ss) and branch points of a FIR/PUF60-dependent exon and the 3'ss choice was also influenced by AS of FIR/PUF60 ${ }^{[65]}$. FIR/FIR $\triangle$ exon2/PUF60 is a promising target to the development of cancer diagnosis and therapies directed HBV, HCV, FBW7 as well as c-Myc. Together, FIR/PUF60/FIR $\Delta$ exon2 are multifunctional through AS and applicable for clinical use for HBV suppression especially for hepatoma treatment.

\section{DECLARATIONS}

\section{Acknowledgements}

The authors appreciate Dr Hiroyuki Osada and his coworkers (RIKEN, Wako, Saitama, Japan) for screening compounds bound to FIR/FIR $\Delta$ exon2 from a chemical library which was a collection of the isolates from natural products.

\section{Authors' contributions}

Made substantial contributions to conception and design of the study and performed data analysis and interpretation: Matsushita K

Performed data acquisition, as well as provided administrative, technical, and material support: Hoshino $\mathrm{T}$

\section{Availability of data and materials}

Materials used in this study are generally available for readers as described in th materials and methods.

\section{Financial support and sponsorship}

This study was supported in part by Grant-in-Aid 26460667 for priority areas in cancer research from "the Ministry of Education, Science, Sports and Culture of Japan” (KAKENHI), AMED (Japan Agency for Medical Research and Development), "Chiba Foundation for Health Promotion \& Disease Prevention" and was partly supported by Extramural Collaborative Research Grant of Cancer Research Institute, Kanazawa University to K.M.

\section{Conflicts of interest}

All authors declared that there are no conflicts of interest.

\section{Ethical approval and consent to participate}

Not applicable.

\section{Consent for publication}

Not applicable. 


\section{Copyright}

(C) The Author(s) 2018.

\section{REFERENCES}

1. Matsushita K, Tomonaga T, Kajiwara T, Shimada H, Itoga S, Hiwasa T, Kubo S, Ochiai T, Matsubara H, Nomura F. c-Myc suppressor FBPinteracting repressor for cancer diagnosis and therapy. Front Biosci (Landmark Ed) 2009;1:3401-8.

2. Pelengaris S, Khan M, Evan GI. Suppression of Myc-induced apoptosis in beta cells exposes multiple oncogenicproperties of Myc and triggers carcinogenic progression. Cell 2002;109:321-34.

3. Bazar L, Meighen D, Harris V, Duncan R, Levens D, Avigan M. Targeted melting and binding of a DNA regulatory element by a transactivator of c-Myc. J Biol Chem 1995;270:8241-8.

4. Michelotti GA, Michelotti EF, Pullner A, Duncan RC, Eick D, Levens D. Multiple single-stranded cis elements are associated with activated chromatin of the human c-Myc gene in vivo. Mol Cell Biol 1996;16:2656-69.

5. Zubaidah RM, Tan GS, Tan SB, Lim SG, Lin Q, Chung MC. 2-D DIGE profiling of hepatocellular carcinoma tissues identified isoforms of far upstream binding protein (FUBP) as novel candidates in liver carcinogenesis. Proteomics 2008;8:5086-96.

6. Malz M, Weber A, Singer S, Riehmer V, Bissinger M, Riener MO, Longerich T, Soll C, Vogel A, Angel P, Schirmacher P, Breuhahn $\mathrm{K}$. Overexpression of far upstream element binding proteins: a mechanism regulating proliferation and migration in liver cancer cells. Hepatology 2009;50:1130-9.

7. Quinn LM. FUBP/KH domain proteins in transcription: back to the future. Transcription 2017;8:185-92.

8. Liu J, Akoulitchev S, Weber A, Ge H, Chuikov S, Libutti D, Wang XW, Conaway JW, Harris CC, Conaway RC, Reinberg D, Levens D. Defective interplay of activators and repressors with TFIH in xeroderma pigmentosum. Cell 2001;104:353-63.

9. Kitamura A, Matsushita K, Takiguchi Y, Shimada H, Tada Y, Yamanaka M, Hiroshima K, Tagawa M, Tomonaga T, Matsubara H, Inoue M, Hasegawa M, Sato Y, Levens D, Tatsumi K, Nomura F. Synergistic effect of non-transmissible Sendai virus vector encoding the c-Myc suppressor FUSE-binding protein-interacting repressor plus cisplatin in the treatment of malignant pleural mesothelioma. Cancer Sci 2011;102:1366-73

10. Kano M, Matsushita K, Rahmutulla B, Yamada S, Shimada H, Kubo S, Hiwasa T, Matsubara H, Nomura F. Adenovirus-mediated FIR demonstrated TP53-independent cell-killing effect and enhanced antitumor activity of carbon-ion beams. Gene Ther 2016;23:50-6.

11. Mizokami D, Araki K, Tanaka N, Suzuki H, Tomifuji M, Yamashita T, Matsushita K, Shimada H, Shiotani A. Tacrolimus prevents laryngotracheal stenosis in an acute-injury rat model. Laryngoscope 2015;125:E210-5.

12. Matsushita K, Shimada H, Ueda Y, Inoue M, Hasegawa M, Tomonaga T, Matsubara H, Nomura F. Non-transmissible Sendai virus vector encoding c-Myc suppressor FBP-interacting repressor for cancer therapy. World J of Gastroenterol 2014;20:4316-28.

13. Mizokami D, Araki K, Tanaka N, Suzuki H, Tomifuji M, Yamashita T, Ueda Y, Shimada H, Matsushita K, Shiotani A. Gene therapy of c-Myc suppressor FUSE-binding protein-interacting repressor by Sendai virus delivery prevents tracheal stenosis. PloS One 2015; doi: 10.1371/journal.pone.0116279.

14. Tanaka N, Araki K, Mizokami D, Miyagawa Y, Yamashita T, Tomifuji M, Ueda Y, Inoue M, Matsushita K, Nomura F, Shimada H, Shiotani A. Sendai virus-mediated gene transfer of the c-Myc suppressor far-upstream element-binding protein-interacting repressor suppresses head and neck cancer. Gene Ther 2015;22:297-304.

15. Black DL. Mechanisms of alternative pre-messenger RNA splicing. Annu Rev Biochem 2003;72:291-336.

16. Matsushita K, Takenouchi T, Shimada H, Tomonaga T, Hayashi H, Shioya A, Komatsu A, Matsubara H, Ochiai T. Strong HLA-DR antigen expression on cancer cells relates to better prognosis of colorectal cancer patients: possible involvement of c-Myc suppression by interferongamma in situ. Cancer Sci 2006;97:57-63.

17. Duriez M, Mandouri Y, Lekbaby B, Wang H, Schnuriger A, Redelsperger F, Guerrera CI, Lefevre M, Fauveau V, Ahodantin J, Quetier I, Chhuon C, Gourari S, Boissonnas A, Gill U, Kennedy P, Debzi N, Sitterlin D, Maini MK, Kremsdorf D, Soussan P. Alternative splicing of hepatitis B virus: a novel virus/host interaction altering liver immunity. J Hepatol 2017;67:687-99.

18. Rahmutulla B, Matsushita K, Satoh M, Seimiya M, Tsuchida S, Kubo S, Shimada H, Ohtsuka M, Miyazaki M, Nomura F. Alternative splicing of FBP-interacting repressor coordinates c-Myc, P27Kip1/cyclinE and Ku86/XRCC5 expression as a molecular sensor for bleomycin-induced DNA damage pathway. Oncotarget 2014;5:2404-17.

19. Rahmutulla B, Matsushita K, Nomura F. Alternative splicing of DNA damage response genes and gastrointestinal cancers. World J of Gastroenterol 2014;20:17305-13.

20. Khageh Hosseini S, Kolterer S, Steiner M, von Manstein V, Gerlach K, Trojan J, Waidmann O, Zeuzem S, Schulze JO, Hahn S, Steinhilber D, Gatterdam V, Tampé R, Biondi RM, Proschak E, Zörnig M. Camptothecin and its analog SN-38, the active metabolite of irinotecan, inhibit binding of the transcriptional regulator and oncoprotein FUBP1 to its DNA target sequence FUSE. Biochem Pharmacol 2017;146:5362.

21. Brinkman BM. Splice variants as cancer biomarkers. Clin Biochem 2004;37:584-94.

22. Matsushita K, Tomonaga T, Shimada H, Shioya A, Higashi M, Matsubara H, Harigaya K, Nomura F, Libutti D, Levens D, Ochiai T. An essential role of alternative splicing of c-Myc suppressor FUSE-binding protein-interacting repressor in carcinogenesis. Cancer Res 2006;66:1409-17.

23. Hastings ML, Allemand E, Duelli DM, Myers MP, Krainer AR. Control of pre-mRNA splicing by the general splicing factors PUF60 and U2AF(65). PLoS One 2007;2:e538.

24. Page-McCaw PS, Amonlirdviman K, Sharp PA. PUF60: a novel U2AF65-related splicing activity. RNA 1999;5:1548-60.

25. Zhang YM, Yang HB, Shi JL, Chen H, Shu XM, Lu X, Wang GC, Peng QL. The prevalence and clinical significance of anti-PUF60 antibodies in patients with idiopathic inflammatory myopathy. Clin Rheumatol 2018;37:1573-80. 
26. Fiorentino DF, Presby M, Baer AN, Petri M, Rieger KE, Soloski M, Rosen A, Mammen AL, Christopher-Stine L, Casciola-Rosen L. PUF60: a prominent new target of the autoimmune response in dermatomyositis and Sjögren's syndrome. Ann Rheum Dis 2016;75:114551.

27. Kobayashi S, Hoshino T, Hiwasa T, Satoh M, Rahmutulla B, Tsuchida S, Komukai Y, Tanaka T, Matsubara H, Shimada H, Nomura F, Matsushita K. Anti-FIRs (PUF60) auto-antibodies are detected in the sera of early-stage colon cancer patients. Oncotarget 2016;7:82493503 .

28. Kobayashi S, Hiwasa T, Arasawa T, Kagaya A, Ishii S, Shimada H, Ito M, Suzuki M, Kano M, Rahmutulla B, Kitamura K, Sawabe Y, Shin H, Takiguchi M, Nomura F, Matsubara H, Matsushita K. Identification of specific and common diagnostic antibody markers for gastrointestinal cancers by SEREX screening using testis cDNA phage library. Oncotarget 2018;9:18559-69.

29. Matsushita K, Tamura M, Tanaka N, Tomonaga T, Matsubara H, Shimada H, Levens D, He L, Liu J, Yoshida M, Nomura F. Interactions between SAP155 and FUSE-binding protein-interacting repressor bridges c-Myc and P27Kip1 expression. Mol Cancer Res 2013;11:68998.

30. Kajiwara T, Matsushita K, Itoga S, Tamura M, Tanaka N, Tomonaga T, Matsubara H, Shimada H, Habara Y, Matsuo M, Nomura F. SAP155-mediated c-Myc suppressor far-upstream element-binding protein-interacting repressor splicing variants are activated in colon cancer tissues. Cancer Sci 2013;104:149-56.

31. Matsushita K, Kajiwara T, Tamura M, Satoh M, Tanaka N, Tomonaga T, Matsubara H, Shimada H, Yoshimoto R, Ito A, Kubo S, Natsume T, Levens D, Yoshida M, Nomura F. SAP155-mediated splicing of FUSE-binding protein-interacting repressor serves as a molecular switch for c-Myc gene expression. Mol Cancer Res 2012;10:787-99.

32. Kotake Y, Sagane K, Owa T, Mimori-Kiyosue Y, Shimizu H, Uesugi M, Ishihama Y, Iwata M, Mizui Y. Splicing factor SF3b as a target of the antitumor natural product pladienolide. Nat Chem Biol 2007;3:570-5.

33. Kaida D, Motoyoshi H, Tashiro E, Nojima T, Hagiwara M, Ishigami K, Watanabe H, Kitahara T, Yoshida T, Nakajima H, Tani T, Horinouchi S, Yoshida M. Spliceostatin A targets SF3b and inhibits both splicing and nuclear retention of pre-mRNA. Nat Chem Biol 2007;3:576-83.

34. Sun S, Nakashima K, Ito M, Li Y, Chida T, Takahashi H, Watashi K, Sawasaki T, Wakita T, Suzuki T. Involvement of PUF60 in transcriptional and post-transcriptional regulation of hepatitis B virus pregenomic RNA expression. Sci Rep 2017;7:12874.

35. Kanoh N, Kumashiro S, Simizu S, Kondoh Y, Hatakeyama S, Tashiro H, Osada H. Immobilization of natural products on glass slides by using a photoaffinity reaction and the detection of protein-small-molecule interactions. Angew Chem Int Ed Engl 2003;42:5584-7.

36. Osada H. Introduction of new tools for chemical biology research on microbial metabolites. Biosci Biotechnol Biochem 2010;74:1135-40.

37. Kawatani M, Fukushima Y, Kondoh Y, Honda K, Sekine T, Yamaguchi Y, Taniguchi N, Osada H. Identification of matrix metalloproteinase inhibitors by chemical arrays. Biosci Biotechnol Biochem 2015;79:1597-602.

38. Malz M, Bovet M, Samarin J, Rabenhorst U, Sticht C, Bissinger M, Roessler S, Bermejo JL, Renner M, Calvisi DF, Singer S, Ganzinger M, Weber A, Gretz N, Zörnig M, Schirmacher P, Breuhahn K. Overexpression of far upstream element (FUSE) binding protein (FBP)interacting repressor (FIR) supports growth of hepatocellular carcinoma. Hepatology 2014;60:1241-50.

39. Loerch S, Kielkopf CL. Unmasking the U2AF homology motif family: a bona fide protein-protein interaction motif in disguise. RNA 2016;22:1795-807.

40. Stepanyuk GA, Serrano P, Peralta E, Farr CL, Axelrod HL, Geralt M, Das D, Chiu HJ, Jaroszewski L, Deacon AM, Lesley SA, Elsliger MA, Godzik A, Wilson IA, Wüthrich K, Salomon DR, Williamson JR. UHM-ULM interactions in the RBM39-U2AF65 splicing-factor complex. Acta Crystallogr D Struct Biol 2016;72:497-511.

41. Loerch S, Maucuer A, Manceau V, Green MR, Kielkopf CL. Cancer-relevant splicing factor CAPER $\alpha$ engages the essential splicing factor SF3b155 in a specific ternary complex. J Biol Chem 2014;289:17325-37.

42. Corsini L, Hothorn M, Stier G, Rybin V, Scheffzek K, Gibson TJ, Sattler M. Dimerization and protein binding specificity of the U2AF homology motif of the splicing factor Puf60. J Biol Chem 2009;284:630-9.

43. Matsushita K, Kitamura K, Rahmutulla B, Tanaka N, Ishige T, Satoh M, Hoshino T, Miyagi S, Mori T, Itoga S, Shimada H, Tomonaga T, Kito M, Nakajima-Takagi Y, Kubo S, Nakaseko C, Hatano M, Miki T, Matsuo M, Fukuyo M, Kaneda A, Iwama A, Nomura F. Haploinsufficiency of the c-Myc transcriptional repressor FIR, as a dominant negative-alternative splicing model, promoted p53- dependent T-cell acute lymphoblastic leukemia progression by activating Notch1. Oncotarget 2015;6:5102-17.

44. Wang Z, Inuzuka H, Fukushima H, Wan L, Gao D, Shaik S, Sarkar FH, Wei W. Emerging roles of the FBW7 tumour suppressor in stem cell differentiation. EMBO Rep 2011;13:36-43.

45. Wang Z, Inuzuka H, Zhong J, Wan L, Fukushima H, Sarkar FH, Wei W. Tumor suppressor functions of FBW7 in cancer development and progression. FEBS Lett 2012;586:1409-18.

46. Ogura Y, Hoshino T, Tanaka N, Ailiken G, Kobayashi S, Kitamura K, Rahmutulla B, Kano M, Murakami K, Akutsu Y, Nomura F, Itoga $\mathrm{S}$, Matsubara H, Matsushita K. Disturbed alternative splicing of FIR (PUF60) directed cyclin E overexpression in esophageal cancers. Oncotarget 2018;9:22929-44.

47. Yanagita H, Urano E, Matsumoto K, Ichikawa R, Takaesu Y, Ogata M, Murakami T, Wu H, Chiba J, Komano J, Hoshino T. Structural and biochemical study on the inhibitory activity of derivatives of 5-nitro-furan-2-carboxylic acid for RNase H function of HIV-1 reverse transcriptase. Bioorg Med Chem 2011;19:816-25.

48. Yanagita H, Fudo S, Urano E, Ichikawa R, Ogata M, Yokota M, Murakami T, Wu H, Chiba J, Komano J, Hoshino T. Structural modulation study of inhibitory compounds for ribonuclease $\mathrm{H}$ activity of human immunodeficiency virus type 1 reverse transcriptase. Chem Pharm Bull (Tokyo) 2012;60:764-71.

49. Fudo S, Yamamoto N, Nukaga M, Odagiri T, Tashiro M, Neya S, Hoshino T. Structural and computational study on inhibitory compounds for endonuclease activity of influenza virus polymerase. Bioorg Med Chem 2015;23:5466-75.

50. Kimura A, Kitamura K, Ailiken G, Satoh M, Minamoto T, Tanaka N, Nomura F, Matsushita K. FIR haplodeficiency promotes splicing to pyruvate kinase M2 in mice thymic lymphoma tissues revealed by six-plex tandem mass tag quantitative proteomic analysis. Oncotarget 2017;8:67955-65. 
51. Dayton TL, Gocheva V, Miller KM, Israelsen WJ, Bhutkar A, Clish CB, Davidson SM, Luengo A, Bronson RT, Jacks T, Vander Heiden MG. Germline loss of PKM2 promotes metabolic distress and hepatocellular carcinoma. Genes Dev 2016;30:1020-33.

52. Gumireddy K, Li A, Yan J, Setoyama T, Johannes GJ, Orom UA, Tchou J, Liu Q, Zhang L, Speicher DW, Calin GA, Huang Q. Identification of a long non-coding RNA-associated RNP complex regulating metastasis at the translational step. EMBO J 2013;32:2672-84.

53. Bowler E, Porazinski S, Uzor S, Thibault P, Durand M, Lapointe E, Rouschop KMA, Hancock J, Wilson I, Ladomery M. Hypoxia leads to significant changes in alternative splicing and elevated expression of CLK splice factor kinases in PC3 prostate cancer cells. BMC Cancer 2018;18:355.

54. Lamontagne RJ, Bagga S, Bouchard MJ. Hepatitis B virus molecular biology and pathogenesis. Hepatoma Res 2016;2:163-86.

55. Dixit U, Pandey AK, Liu Z, Kumar S, Neiditch MB, Klein KM, Pandey VN. FUSE binding protein 1 facilitates persistent hepatitis C virus replication in hepatoma cells by regulating tumor suppressor p53. J Virol 2015;89:7905-21.

56. Samarin J, Laketa V, Malz M, Roessler S, Stein I, Horwitz E, Singer S, Dimou E, Cigliano A, Bissinger M, Falk CS, Chen X, Dooley S, Pikarsky E, Calvisi DF, Schultz C, Schirmacher P, Breuhahn K. PI3K/AKT/mTOR-dependent stabilization of oncogenic far-upstream element binding proteins in hepatocellular carcinoma cells. Hepatology 2016;63:813-26.

57. Rabenhorst U, Beinoraviciute-Kellner R, Brezniceanu ML, Joos S, Devens F, Lichter P, Rieker RJ, Trojan J, Chung HJ, Levens DL, Zörnig M. Overexpression of the far upstream element binding protein 1 in hepatocellular carcinoma is required for tumor growth. Hepatology 2009;50:1121-9.

58. Moccia A, Srivastava A, Skidmore JM, Bernat JA, Wheeler M, Chong JX, Nickerson D, Bamshad M, Hefner MA, Martin DM, Bielas SL. Genetic analysis of CHARGE syndrome identifies overlapping molecular biology. Genet Med 2018; doi: 10.1038/gim.2017.233.

59. Zhao JJ, Halvardson J, Zander CS, Zaghlool A, Georgii-Hemming P, Månsson E, Brandberg G, Sävmarker HE, Frykholm C, Kuchinskaya E, Thuresson AC, Feuk L. Exome sequencing reveals NAA15 and PUF60 as candidate genes associated with intellectual disability. Am J Med Genet B Neuropsychiatr Genet 2018;177:10-20.

60. Low KJ, Ansari M, Abou Jamra R, Clarke A, El Chehadeh S, FitzPatrick DR, Greenslade M, Henderson A, Hurst J, Keller K, Kuentz P, Prescott T, Roessler F, Selmer KK, Schneider MC, Stewart F, Tatton-Brown K, Thevenon J, Vigeland MD, Vogt J, Willems M, Zonana J, Study DD, Smithson SF. PUF60 variants cause a syndrome of ID, short stature, microcephaly, coloboma, craniofacial, cardiac, renal and spinal features. Eur J Hum Genet 2017;25:552-9.

61. Santos-Simarro F, Vallespin E, Del Pozo A, Ibañez K, Silla JC, Fernandez L, Nevado J, González-Pecellín H, Montaño VEF, Martin R, Alba Valdivia LI, García-Miñaúr S, Lapunzina P, Palomares-Bralo M. Eye coloboma and complex cardiac malformations belong to the clinical spectrum of PUF60 variants. Clin Genet 2017;92:350-1.

62. Graziano C, Gusson E, Severi G, Isidori F, Wischmeijer A, Brugnara M, Seri M, Rossi C. A de novo PUF60 mutation in a child with a syndromic form of coloboma and persistent fetal vasculature. Ophthalmic Genet 2017;38:590-2.

63. Wells C, Spaggiari E, Malan V, Stirnemann JJ, Attie-Bitach T, Ville Y, Vekemans M, Bessieres B, Romana S. First fetal case of the 8q24.3 contiguous genes syndrome. Am J Med Genet A 2016;170A:239-42.

64. Dauber A, Golzio C, Guenot C, Jodelka FM, Kibaek M, Kjaergaard S, Leheup B, Martinet D, Nowaczyk MJ, Rosenfeld JA, Zeesman S, Zunich J, Beckmann JS, Hirschhorn JN, Hastings ML, Jacquemont S, Katsanis N. SCRIB and PUF60 are primary drivers of the multisystemic phenotypes of the 8q24.3 copy-number variant. Am J Hum Genet 2013;93:798-811.

65. Královicová J, Ševcíková I, Stejskalová E, Obuca M, Hiller M, Stanek D, Vorechovský I. PUF60-activated exons uncover altered 3' splicesite selection by germline missense mutations in a single RRM. Nucleic Acids Res 2018;46:6166-87. 